Boise State University

ScholarWorks

Political Science Faculty Publications and

Presentations

Department of Political Science

4-1-2009

Following in the Footsteps of Policy Entrepreneurs: Policy Advocates and Pro Forma Adopters

Brian Wampler

Boise State University 


\title{
Following in the Footsteps of Policy Entrepreneurs: Policy Advocates and Pro Forma Adopters
}

\author{
Forthcoming, Journal of Development Studies
}

\begin{abstract}
Brian Wampler
bwampler@boisestate.edu

Please contact the author with any comments or feedback. This is not the final version of the article. It will be copyedited by the Journal of Development Studies.
\end{abstract}

\begin{abstract}
The third wave of democratization has been accompanied by the spread of new institutions that allow citizens to directly participate in shaping policy outcomes. Leading international organizations, such as the World Bank and UN Habitat, have disseminated "best practice” programs identified with "good government” policy reform efforts. One of the most well-known programs, Participatory Budgeting (PB), was first adopted by an entrepreneurial government in 1989 as a means to promote social justice, accountability, and transparency. Yet, when these programs are copied by policy advocates and pro forma adopters the political pay-offs for government officials are smaller, which leads them to provide weaker support for the adopted policy. This article demonstrates that policy entrepreneurs are more likely to provide greater resources and support to innovative policies than their policy advocates and pro forma adopter counterparts due to types of political payoffs available to them. The article concludes by considering when it might be most appropriate for international funding agencies and nongovernmental organizations to promote best practice policies.
\end{abstract}

Key words: participatory democracy, Brazil, best practices, policy entrepreneurs, policy advocates, pro forma adopters, diffusion 


\section{Adopting Innovative Policies}

Governments adopt innovative, "best practice" policies in the hopes that these successful policies will help them to solve basic governing problems. Although considerable theoretical, policy, and political attention has been paid to the role of entrepreneurial subnational governments during the initial founding of these policies, there has been insufficient analysis of the interests, strategies, and incentives of governments that copy the best practices initiated by policy entrepreneurs (Abers 2000; Baumgartner and Jones 1993; Grindle 2000; Heller 2000; Kingdon 1995; Tendler 1997). Governments that copy best practice policies often do so based on the purported successes of the founding cases; it is their quite reasonable expectation that successful policy programs, policies, and ideas can help them to improve their electoral and governing outcomes. Yet, we lack a theoretical explanation for when and how adopting government officials will provide necessary support to allow the adopted policy to succeed. How does the presence of policy entrepreneurs, policy advocates, or pro forma adopters affect the likelihood that a government will produce an outcome similar to the best practice policy?

A common thread present in many accounts of the best practices policy debate is the importance of the government's political will or interest in promoting the program (Abers 2000; Goldfrank 2007b; Navarro 2003; Schneider and Teske 1992). According to this line of analysis, meaningful reform efforts are driven by the interests of government officials to help to achieve their preferred policy and political outcomes (Grindle 2000; Tendler 1997). Over the past decade, considerable effort has been made by the World Bank and United Nations Habitat to promote the adoption of best practice policies, for 
the obvious reason that learning from the successful policy reform efforts may help to more quickly alleviate intense social problems (Shah 2007; Cabannes 2004). However, we continue to lack basic theoretical and analytical understandings to account for if and when the adopted policies are likely to perform similarly to the initial set of cases, which are often highly successful. ${ }^{1}$

The expansion in the number of democratic regimes over the past thirty years has been accompanied by the adoption of policy making institutions that provide citizens with direct access to decision making venues (Avritzer 2002; Grindle 2000; Heller 2000; Shah 2007). Governments hope that the incorporation of citizens into state-sanctioned policy spaces can improve the efficiency of government while also deepening the quality of democracy (Genro 1995; Baiocchi 2005). It may appear to UN Habitat and World Bank officials that adoption of best practice policies is necessary to produce the right set of institutions to foster social and economic development, but we must consider that the adoption of best practice policies and institutions in unsuitable political environments may explain why so many governments struggle to produce public policies that improve the quality of life of their citizens. It is possible that the adoption of democratic institutions may not just be merely unsuccessful. Rather, there is considerable risk that the adoption of democratic policies and institutions that perform poorly can potentially undermine reformers and civil society activists who seek to use these policies to deepen the quality of local democracy.

To explain the varying roles played by government officials during the adoption of best practice policies, this article analyzes eight cases of participatory budgeting (PB) in Brazil. The interests, strategies, and incentives of government officials, often vaguely 
described as "political will," are central to this analysis because governments must take legal and policy steps to establish participatory policy programs (Navarro 2003; Cabannes 2004). Although civil society, institutional, and socio-economic factors obviously affect public policy outcomes, especially in participatory budgeting because citizens theoretically have the right to define portions of the budget, this article narrows the scope of analysis to focus on the political incentives that induce government officials to take specific steps to allow them to promote the successful implementation of the new policy. This approach helps us to introduce political factors associated with leadership that the social sciences have had such a difficult time incorporating into explanation of policy outcomes. Participatory budgeting is a particularly important case study because there are now hundreds of local governments in Brazil and thousands more across the globe that have adopted institutions based on the pioneering case of Porto Alegre (Goldfrank 2007a and 2007b; Torres and Grazia 2003; Nylen 2003; Cabannes 2004; Wampler and Avritzer 2005; Wampler 2007a).

This article proceeds in the following fashion. First, a brief theoretical discussion of the well-known category of policy entrepreneur shows that there are specific types of political pay-offs for these political leaders (Kingdon 1995; Baumgartner and Jones 1992; Mintrom 1997). This section is followed by the introduction of two new categories: policy advocates and pro forma adopters, to theoretically distinguish between the expected benefits for these governments from their adoption of innovative policies as well as to theoretically demonstrate a link between their incentives to adopt and the degree of support they provide during the policy's implementation phase. The second section introduces readers to PB and describes the characteristics associated with its 
diffusion in Brazil during the 1990s. The third section analyzes eight cases of PB to demonstrate how the differing political payoffs for government officials vis-à-vis their adoption of PB significantly affect their commitment to providing the resources that would allow PB to flourish. The article concludes with a discussion in which I argue that best practices can produce positive effects when policy advocates adopt the program, although these effects are likely to be weaker than the pioneering cases. More worrisome, however, are the pro forma adopter cases, because these programs are more likely to produce weak outcomes, thereby calling into question whether policy adoption should be promoted in policy and political environments in which there are weak incentives for government leaders to benefit from the program.

\section{Policy Entrepreneurs}

Policy entrepreneurs expend considerable time, energy, and resources to initiate policies because of the potential policy and political benefits engendered by redesigning the policy arena (Kingdon 1995, Baumgartner and Jones 1993; Tendler 1997; Mintrom 1997). Kingdon describes policy entrepreneurs as being "willing to invest their resources - time, energy, reputation, money_to promote a position in return for anticipated future gain in the form of material, purposive, solidary benefits” (Kingdon 1995, p. 179). Schnieder and Teske argue “entrepreneurs are more likely to emerge when there are factors that make entrepreneurial profits more likely and where local conditions facilitate a solution to collective action problems” (Schneider and Teske 1992: 742). Policy entrepreneurs therefore emerge when there is a window of opportunity in which they, as individual politicians or as members of a party, benefit from the success of the 
innovative policies. The benefits may include modifying the party system to their advantage, pushing through policies to benefit their strongest supporters, reaching out to new constituent groups, helping them to re-position the party in the public's eyes, or producing a policy change that pushes government officials into the national or international policy spotlight.

The benefits that accrue to an entrepreneurial local government are situated within electoral and governing processes at local and national levels, identified below in Table 1. The adoption of an innovative policy by a policy entrepreneur has three significant pay-offs at the local level: (a) the potential to reward the entrepreneur's political base by crafting new rules and institutional arrangements that provide access points or direct benefits that were not previously available; (b) the opportunity to reach out to individuals who were not traditionally part of the governing coalition; and (c) the opportunity to rebrand the party as modern, inclusive, and innovative. All three of these factors directly affect a government's re-election strategies and the last two factors can influence public opinion by inducing shifts in attitudes among individuals who were not previously supporters.

\section{Insert Table 1 here}

The adoption of an innovative policy has two potential pay-offs outside the local community: (a) Government officials are rewarded politically, professionally, and sometimes financially, by national and international organizations for their innovative work. For example, national and international organizations offer "best practice” awards and small cash prizes to winning governments. Politicians and government officials often cite this recognition as proof that they are on the cutting edge of policy reform; and (b) 
Government officials are rewarded within their party for adopting innovative policies, especially when it reinforces the party brand that national party leaders are seeking to establish. To expand their influence, policy entrepreneurs may also seek to diffuse their policies in order to build a base of support and to capture credit for having initiated programs that are being copied. Schneider and Teske argue “ambitious local entrepreneurs may seek to have their innovations imitated elsewhere to develop a broader reputation and to increase the rewards of their entrepreneurial activities” (Schneider and Teske 1992: 740; see also Grindle 2000). The diffusion of the adopted policy by policy entrepreneurs suggests that they seek out similar governments to follow their successful policies.

\section{Policy Advocates}

Policy advocates are government officials who initiate a policy based on the purported successes of the policy but only give partial support to the policy's central components because their political benefits are more limited than the benefits accrued by policy entrepreneurs. Policy advocates can claim credit for introducing a policy that has been successfully implemented elsewhere but two publics, voters and high-level party officials, do not necessary grant them the same credit for adoption that the policy entrepreneurs gained for innovation.

Of course, there are some political and policy benefits which helps to explain why governments partially support the adoption of the policy program. As shown in Table 1, government officials are likely to adopt a policy in response to the political demands of a faction of their political coalition; adoption of the innovative policy allows them to 
reward this faction of their political base. However, government officials do not necessarily utilize the policy program to reach out to citizens who were not previously supporters of the governing party. The adoption of the policy program doesn't allow the governing party to re-brand itself because government officials cannot claim that they are initiating a bold new strategy to revamp the policy arena. Rather, the government can assert that the adopted policy has been "remodeled" to allow them to create an even better policy program than the original cases. Successfully adopting a policy that has been initiated elsewhere may earn government officials recognition as being good administrators, but it will not reward them as policy entrepreneurs who might be able to lead the party in new directions. Therefore, the potential benefits that accrue to the governing party are significantly lower than the potential benefits available for policy entrepreneurs.

\section{Pro Forma Adopters}

Pro forma adopters receive very limited direct political benefits from their adoption of an innovative policy. Why do they adopt a policy when the perceived benefits are low? Adoption is likely to occur when pro forma government officials are induced by national party leaders to follow the party line by adopting a policy associated with the government, when a small faction of their party insists upon the adoption of the policy, or when national or international institutions requires adoption (Goldfrank 2007b; Wampler 2007a). Since the government officials’ political pay-offs are low, they will likely dedicate only minimal levels of time, energy, and resources that are necessary to make the innovative policy successful. Quite simply, the adopted policy is not at the core 
of the government's policy and/or political agenda. The policy is added onto an existing political and policy agenda, which means that the government officials will not likely dedicate their best personnel to the policy program or provide the necessary funds to ensure success. At the heart of this category is the assumption that pro forma adopters have been induced by individuals or institutions outside of the government's core decision making group to adopt a policy that government officials would otherwise not have adopted.

A brief glance at Table 1 shows that pro forma adopter governments receive very limited electoral, governing, or political benefits from their decision to adopt the policy. The political base that the adopted policy is supposed to reward is likely too small or is already a captured group, which means that the government doesn't need to spend its time shoring up its base. There are too few civil society organizations or those that exist are securely captured by rival parties, which mean that the government can not use the policy to recruit new supporters. In addition, the policy doesn't re-brand the party in the way that corresponds with how the local party leadership in trying to position itself in electoral arenas. Finally, the national party leadership doesn’t recognize their policy adoption as noteworthy, but, rather, the adoption can create positive outcomes for national party leaders if they want to claim that they are a party of reformers as based on the evidence that most of their important subnational governments adopted the innovative policy. In sum, the adopted policy presents limited opportunities for the government to gain politically, which suggests that the adopted policy will not enjoy the steadfast support of government officials. 


\section{From adoption to implementation}

Based on the analysis presented in the previous section, there are greater political rewards for policy entrepreneurs than for policy advocates or pro forma adopters in their search to adopt policies and institutional arrangements that distinguish them from their competitors. Likewise, it is reasonable to assert that greater political rewards will be available to entrepreneurs based on the outcomes of the programs; politicians who initiate reform projects will get more political credit for the program’s successful outcomes than government officials who are viewed as good administrators. This is not to deny that good administrators can and do gain votes on the basis of their strong administrative skills, but the point is to highlight that the gains accrued from policy outcomes will vary based on government's role in initiating policy change.

Political entrepreneurs are more likely to dedicate greater resources (such as personnel, administrative support, budget outlays) than policy advocates or pro formal adopters because their political careers depend on cementing the policy shifts they initiated. If the programs fail, the policy entrepreneur's loyal supporters may be disenchanted or even exit the party, individuals that they sought to reach out to will migrate to their competitors, their attempt to re-brand the local party will appear to have been grounded in political marketing rather than substantial change, and the attention that they drew from national party leaders and international organizations will dissipate. For policy entrepreneurs, the policy innovation is central to their governing and political futures, which means that they concentrate the majority of their attention on the program to the exclusion of other areas. 
The potential risks are not so great for the policy advocates because it is far easier for them to distance themselves from the program. Policy advocates, as detailed in Table 1, are likely to accrue some benefits from their adoption and the same logic applies to policy implementation. Since the government is only partially tied to the policy, a broader array of public policies are used to secure constituents' and party members’ support rather than just one particular policy. Efforts to re-brand the party take multiple routes, which suggest that the party’s broad message will include the innovative policy in conjunction other issues. Finally, since the gains are lower within national party and international organizations, there is a weaker incentive to implement the policies in a way that maintain the attention of national party leaders. Rather, improvements may be made at the margins (Within PB, this would include programs such as PB Kids and Adolescents, PB Housing, PB Affirmative Action) but that the core set of benefits for the government is limited. Therefore, policy advocates will dedicate some support to implementation but their support will be more limited than the support provided by policy entrepreneurs.

Pro forma adopters receive few political, policy, or governing benefits from their adoption of the program. They are induced, as argued above, to adopt from internal pressure from a minority part of their political coalition, national party leaders or from international organizations. Just as their benefits from adoption are low, so too are their benefits from the potential success of the program. Governments are therefore likely to invest lower levels of resources because they are not necessarily going to benefit politically from the process. Pro forma adopters won't use the policy as the primary strategy to reward their base of support, to reach out to new sectors, to re-brand their 
party, or to gain the attention of national and international actors. Although it might appear to be nonsensical for pro forma government leaders to adopt a policy to which they are not committed, their limited efforts to ensure successful policy implementation suggests that the government adopts an innovative policy to satisfy one constituency but then dedicates the majority of its limited resources to other projects. An analysis of eight cases of one policy type, Participatory Budgeting, should make this more apparent.

\section{What Is Participatory Budgeting?}

Brazil's federal system provides municipalities with nearly fifteen percent of all public spending, which helps to explain why social movements, non-government organizations, neighborhood associations, and politicians have focused so much attention on budgets at the municipal level (Montero 2000; Montero and Samuels 2004; Wampler 2007a). Brazilian mayors enjoy considerable autonomy, which allows them to initiate new programs with only minimal interference from municipal legislative chambers (Wampler 2007a).

Participatory budgeting is a yearlong decision-making process in which citizens negotiate among themselves and with government officials in organized meetings over the allocation of new capital investment spending on projects, such as health care clinics, schools, and street paving (Abers 2000; Baiocchi 2005; Nylen 2003; Wampler and Avritzer 2004). ${ }^{2}$ It is an innovative program because PB’s rules promote social justice by guaranteeing more resources for poorer neighborhoods, encourage participation by distributing resources within each of the municipality's regions based on the mobilization of community members, and establish new accountability mechanisms to shine light on 
obscure budgetary procedures. In the more successful cases, citizens have authority to make important policy decisions, which has the potential to alter the basic decisionmaking process in Brazilian politics (Abers 2000; Wampler 2007a). PB programs combine elements of direct democracy (i.e., direct mobilization of citizens in decisionmaking venues) and representative democracy (i.e., election of representatives).

PB was initially part of a broader transformative political project that the Workers’ Party (PT) leadership believed would create new types of citizens and transform state-society relations by delegating authority to citizens (Genro 1995; Avritzer 2002). Most scholarly analyses suggest that the pioneering case of Porto Alegre has helped to foster deliberation, social justice, and social capital (Abers 2000; Avritzer 2002; Baiocchi 2005; Marquetti 2003). Comparative research has confirmed that the noteworthy successes of Porto Alegre have not necessarily been matched elsewhere (Nylen 2003; Wampler and Avritzer 2004; Wampler 2007a; Goldfrank and Schneider 2006; Goldfrank 2007a and 2007b). Although the broader transformations hoped for and advocated by the PT and its civil society allies have not yet materialized, PB has been recognized as a policy that induces municipal governments to overhaul their standard policy-making processes. PB has become part of a package of reforms associated with “good government” practices (Hunter 2004; Wampler and Avritzer 2005). Participatory Budgeting received international attention when the United Nations named it one of the best 40 practices at the 1996 Istanbul Habitat Conference. 
Explaining Adoption during PB's First Wave: 1989-1996

PB's birthplace is commonly recognized as being in the southern capital city of Porto Alegre, where the Workers' Party (PT) was elected to the mayor's office in 1988 (Abers 2000; Fedozzi 1998). The PT government worked closely with local civil society organizations to develop the basic set of rules to create a participatory institution that would come to be known as PB (Avritzer 2002; Fedozzi 2001). The PT leadership in Porto Alegre exhibited many of the classic characteristics of policy entrepreneurspolitical outsiders who used their unexpected electoral victory to experiment with new policies and to build a solid base of constituents (Abers 2000; Fedozzi 1998).

Beyond Porto Alegre, PT governments across Brazil were engaged in efforts to initiate policy reforms that would enable them to demonstrate that their governments were doing something different; the PT to establish a "PT way of governing" that would transform Brazilian politics and society (Keck 1992; Couto 1995; Hunter 2004). The PT's electoral victories in 1988 and 1992 came in large, wealthy municipalities that had higher HDI scores than comparable municipalities. ${ }^{3}$ Although the PT positioned itself as the party that would transform the lives of Brazil's excluded and disenfranchised, its principal base of support initially came from union and middle-class sectors who were far better off than the majority of their fellow citizens (Keck 1992; Samuels 2004).

Therefore, PB was a strategy utilized by the PT to shore up their base of support among previously organized groups as well as to reach out to unorganized groups (Nylen 2003; Abers 2000: Baiocchi 2005).

During the 1989-1992 period, the PT governed nine of ten large municipalities that adopted PB. All ten municipalities were in the industrial South and Southeast region 
of the country. The only non-PT adopting government (Vila Velha) was located next to a capital city (Victoria) that was governed by the PT and had adopted PB. It is important to note that not all PT governments during this period were led by policy entrepreneurs but that the initial and most successful case of PB, Porto Alegre, was led by policy entrepreneurs.

During the 1993-1996 period, the PT governed 12 of 17 large municipalities that adopted PB (66\%), as shown in figure 1 below. For the entire 1989-1996 period, the PT governed 21 of the 27 municipalities that adopted PB (78\%). Clearly, the PT was at the center of efforts to promote the adoption of PB. All PT governments in large municipalities (more than 100,000 residents) adopted PB between 1989 and 2004. PT officials in Porto Alegre and in São Paulo disseminated information on this program, especially after Porto Alegre was perceived to be a success (Villas Boas 2004; Assis 1998; Soler 1998; Fedozzi 1999).

\section{Figure 1 about here}

PB's Adoption between 1997 and 2004

There were different incentives for the adoption of PB during the 1997-2004 period as the potential gains for politicians to enhance their reputations as innovative and groundbreaking were much weaker. Policy advocates and pro forma adopters were more likely to emerge during this "second wave" period due to the decline in benefits that could be accrued by government officials. During the 1997-2000 period, it is not the presence of the PT that best explains the adoption of PB programs because the majority of adopters are from political parties other than the PT. The 1996 elections were terrible 
for the PT, which explains why there was a drop in adoption by PT governments during the 1997-2000 period. Centrist (PMDB and PSDB) and leftist political parties (Green Party and Brazilian Socialist Party) adopted PB during this period, attempting to draw on the national and international prestige associated with PB. Although the PT did poorly in the 1996 elections, the Porto Alegre elections produced positive results for the local PT as they won their third consecutive mayoral election, which helps to explain why so many politicians were willing to look at this case that was named on the UN Habitat's best practices in 1996. Centrist and leftist political parties were willing to adopt PB because of the electoral advantages that they might gain (if PB has worked so well for the PT in Porto Alegre, then perhaps it can provide dividends for us) as well as in policy venues (if the PT government is being recognized around the world as a pioneering case, perhaps our adoption of PB will help to brand us as modern, democratic, and participatory).

During the 2001-2004 period, the presence of the PT in the mayor's office is the single strongest factor that explains the likelihood that a municipality would adopt PB, as PT governments adopted 36 percent of new PB programs. These governments consisted largely of policy advocates and pro forma policy adopters, because the governments were being induced by national party leaders and their political base to adopt PB. Politicians from other parties (64\% of the total) continued to adopt PB due, in part, to the growing number of policy and academic evaluations of Porto Alegre’s PB, which largely confirmed that PB was having positive policy and political effects. The PT government in Porto Alegre won its fourth consecutive election in 2000 and was helping to transform democratic politics and was successfully promoting social justice (Marquetti 2003; Abers 
2000; Baiocchi 2005). The PT lost the 2004 mayoral election, thus ending its 16-year hold on Porto Alegre's mayoral office and control of the PB program it had helped to establish.

PB has spread across Brazil, but to what end? What is the impact of these programs? Do participants have any real, substantive powers? These empirical questions are commonly asked by citizens, social scientists, and government officials because they want to know if the impacts of PB are similar to those of the most widely known cases (Porto Alegre, in particular). The remainder of this article focuses on eight cases of PB to initiate a discussion regarding whether the promotion of best practices produces the desired effects.

\section{Policy Entrepreneurs, Policy Advocates, and Pro Forma Adopters}

To demonstrate a link between government action and policy outcomes, I draw from data collected on eight municipalities that adopted PB between 1989 and $2004{ }^{4}$ Extensive field research on this participatory institution conducted by the author shows that two measures serve as excellent indicators to demonstrate policy outcomes (Wampler 2007a and 2007b). The first measure is the percentage of new capital spending that the government allows PB delegates to negotiate. This measure captures the degree of political risk that mayors are willing to take when they delegate authority; Brazilian mayors have considerable discretion over budgetary matters, so an increase in the level of resources that $\mathrm{PB}$ delegates can negotiate within $\mathrm{PB}$ is an indication of increased support for PB by the mayor. Among the eight cases, the percentage of new capital spending that citizens negotiate ranges from a high of $100 \%$ to a low of $10 \%$. This factor demonstrates 
the degree of risk and commitment that government officials are willing to place in this innovative policy-making institution.

The second measure is the percentage of surveyed PB delegates who declare that they "always" or "almost always" have the authority to make policy decisions within PB. The survey was conducted among PB Delegates_citizens elected by their fellow participants to exercise specific decision making authority in the process. PB delegates are often a political elite within the process and have increased information and knowledge of how the process works. The survey results illustrate the degree to which the most active participants believe that PB is allowing them to be directly involved in shaping public policy outcomes. ${ }^{5}$ When citizens believe that they have greater levels of authority, it is a by-product of governments' provision of the necessary administrative, financial, and political support required necessary to create a vibrant program. Thus, higher levels of positive responses indicate that government officials are taking the necessary steps to ensure a successful policy process as well as successful policy outputs. The positive responses (always or almost always exercise authority) range from a high of 67 percent (Porto Alegre) to a low of 15 percent (Rio Claro). I complement the survey and budgetary analysis with elite interviews, participant observations, publications (scholarly, governmental, and NGO-produced), and budgetary data to better classify the government leaders as entrepreneurs, advocates, or pro forma adopters. ${ }^{6}$

Figure 2, below, shows that there is a strong association between survey respondents' attitudes about their level of authority in $\mathrm{PB}$, the resources delegated to $\mathrm{PB}$, and government leadership type. Thus, conceptualizing the governments as entrepreneurs, advocates, or pro forma adopters offers strong analytical leverage to 
understanding the impact of policies adopted by governments seeking to emulate policy entreprenuers. The presence of a policy entrepreneur in the mayor's office is strongly correlated with positive response rates from survey respondents and high spending allocations. Entrepreneurs have staked their political future on the flourishing of this one policy type, which helps to explain why successful policy outcomes were produced. At the other extreme, survey respondents in municipalities with pro forma adopter mayors have weak responses on authority-related questions, suggesting that their PB programs are not working as originally intended, due to the low levels of resources dedicated to the programs. The participants don't have the support of the government, which suggests that these weak cases of PB have a counterproductive effect: Citizens are drawn into a government body with the expectation that they would be contributing to policy-making, only to discover that they are working in a weak institution that offers them few opportunities to reshape policy processes or outcomes.

\section{Figure 2 about here}

The middle cases, led by policy advocates, show moderately positive results, with an average of 47 percent of the survey respondents stating that they always or almost always have the authority to make decisions. In these cases, the lower levels of resources dedicated to the programs and the split among participants' attitudes demonstrates why these four municipalities should be classified as policy advocates—sufficient resources and support were provided by the government to enable the programs to partially succeed, but the level of support was far lower than the resources provided by the entrepreneurial governments. 


\section{Policy Entrepreneurs}

Policy entrepreneurs led two municipalities—Porto Alegre and Ipatinga. Porto Alegre was the birthplace of PB in 1989, although there were previous decentralized, participatory experiences elsewhere in Brazil. From 1989 to 1996, Porto Alegre’s PB was led by two mayors, Olivio Dutra and Tarso Genro, who built local, national, and international reputations based on the success of Porto Alegre's PB. The PT won four successive mayoral elections, with PB at the center of their governing program. PB helped the PT leadership appeal to its base, reach out to new constituents and help to brand the party as participatory and democratic (Abers 2000; Avritzer 2002; Baiocchi 2005; Fedozzi 1998). As noted above, mayors Dutra and Genro became national figures within the PT, both serving as Ministers during President Lula’s two terms in office.

Ipatinga initiated a scaled-back version of PB in 1990 and significantly overhauled it in 1997 to make it similar to Porto Alegre's pioneering model. The mayor who implemented PB in Ipatinga was elected mayor three times $(1988,1996,2000)$ and to the federal congress in 1992 when constitutional rules prohibited him from running for re-election as mayor in 1992. In Porto Alegre and Ipatinga, the PT leaders built their political careers within the PT and in each respective municipality on the promotion of PB (Wampler 2007a).

In Porto Alegre, 100 percent of new capital spending was decided by delegates, which suggest that the government was willing to take substantial political risks to establish the foundations for a new democratic policy-making process (Wampler and Avritzer 2004; Wampler 2007a). As evidenced by the positive responses of citizens, the government provided the necessary support to give citizen voice and vote within PB. 
Between 1995 and 2003, the government implemented over US \$400 million in projects that had been selected by citizens through democratic voting processes within PB (Wampler 2007a). The government took considerable risks to adopt a radical decisionmaking body and the evidence indicates that the government solidified its reputation by providing the necessary resources to allow the innovative program to work well.

In Ipatinga, 50 percent of new capital investment funds were directly decided by citizens, but, importantly, the government also created a parallel process within PB to have citizens select major infrastructure project that could only be implemented if the local government successfully captured state and federal funds. The result was that nearly 75 percent of new capital spending was decided in PB (Wampler 2007a). The government designed new processes for incorporating citizens so they added an on-line Internet presence as well as a rural region (Martinez 2003; Martinez, Vaz, and Carty 2004). The government provided extensive administrative support to create well-run meetings and to ensure that selected projects would be implemented in a timely fashion.

Porto Alegre and Ipatinga’s PB programs were initiated in 1989 and 1990 during a window of opportunity in which the Workers' Party was attempting to build a base of support and to demonstrate that they could offer creative governing solutions to seemingly insurmountable social problems. The mayors and governing coalitions elected in both cities spent considerable political, administrative, and financial capital to adopt and support PB programs. Winning four consecutive elections and vaulting their local leadership into national political circles demonstrates that their political risk-taking was rewarded by voters and national politicians. 


\section{Pro forma adopters}

Blumenau and Rio Claro both initiated PB in 1997 and are classified as pro forma adopters due to the governments' disinterest in providing the administrative and financial resources that are crucial to the success of PB. Remarkably, when I conducted interviews in Blumenau, PB administrators openly talked about how poorly their program worked, which was a significant change from other places with weak or mediocre PB programs where it was often more likely that PB administrators would describe their programs as in the process of improving but just needing some “adjustments.” In Blumenau, a government official complained, "PB has always been weak here... They [government officials] do it because they are supposed to...but the government doesn’t support it.”7

In Blumenau, a PT mayor was elected in 1996 and was persuaded by a minority group within his party to adopt PB in 1997. The government, however, dedicated few resources to the program because the PT mayor did not utilize PB as a way to gain support in Blumenau’s dense civil society (Andrade 2001). PB was not the preferred strategy for the mayor to re-brand the party; an emphasis on large infrastructure projects was emphasized. Thus, as shown in Figure 2 above, the government dedicated few resources to PB. In Rio Claro, the mayor was a reformist from the Green Party. He adopted PB in 1997 but dedicated more of his time, energy, and resources to policies other than PB. The mayor adopted PB at the behest of civil society activists as well as to appeal to Rio Claro’s middle class, which was interested in good government programs (Teixeira and Albuquerque 2005). In both cities, their governments copied the Porto Alegre model with only a few minor modifications, which suggests that both cities lacked 
the presence of an individual or a group dedicated to adapting the basic ideas associated with PB to the local contexts.

The level of new capital spending negotiated in PB corresponds closely with the survey respondents’ belief that they have little authority. In Blumenau, the mayor allowed citizens to negotiate roughly 15 percent of new capital spending (Wampler 2007a). Just 37 percent of the surveyed respondents believed that they had authority to make basic decisions within the PB process. PB formally existed but the citizens used a series of other institutional and extra-institutional channels to secure their policy preferences. The mayor's principal policy initiative during his two terms in office was to secure federal loans to help revitalize their downtown. Thus, efforts to brand the local PT were based on the mayor's ability to implement large restructuring projects rather than on the incorporation of citizens into PB. This is not to argue that the mayor should have chosen to invest more of his political capital into PB rather than his large restructuring projects, but the point is that the mayor adopted PB due to the interests of two groups (junior partner in coalition and national level elites), which explains why only low levels of support were provided in Blumenau

In Rio Claro, the mayor (Green party) allowed citizens to negotiate less than 5 percent of new capital spending (Wampler 2007a). The mayor implemented PB as part of a broad package of reforms. However, civil society organizations were weak so PB did not serve as a tool to reward the base or to recruit new members (Teixeira and Albuquerque 2005). The mayor sought to brand the local Green Party as creating innovative and environmentally sensitive solutions to the municipality's large agriculture industry. PB meetings were limited in scope, with only one annual municipal-wide 
meeting, which was dominated by the mayor and his staff (Teixeira and Albuquerque 2005). PB was formally adopted but the government offered little support to the program. The survey respondents' attitudes reflect the low levels of support provided by the government to $\mathrm{PB}$ : just 15 percent believe that they always or almost always have the ability to exercise authority.

The mayors of Blumenau and Rio Claro did not take the political risks necessary to create vibrant PB programs. Consequently, they did not delegate much authority to citizens or work to ensure the success of PB because it was not vital to their political goals. Pro forma adopters were unwilling to devote the resources, time, energy, and political will to make policy programs successful. They adopted a best practice at the behest of their political party, or to appeal to specific groups of activists and voters, but the mayors did not delegate the necessary resources to produce results that would resemble the most successful cases.

\section{Policy Advocates}

The leadership in the four remaining cases, Santo André, Belo Horizonte, Recife, and São Paulo, are best classified as policy advocates. Government leaders in each municipality were willing to experiment with a new institutional format that could potentially transform basic decision-making processes in each municipality. Yet, the mayors were unwilling to take the political risk of having citizens directly decide substantial portions of new capital spending. Instead, fluctuating levels of authority based on unclear and ever-changing criteria made it difficult for PB participants to devise strategies to secure their preferred policy outcomes. Although each municipality drew 
from the Porto Alegre experience, the mayoral administrations were unwilling to dedicate the necessary time, energy, and resources to the programs to make them successful. The survey responses on authority are all moderately positive, with just under 50 percent asserting that they always or almost always exercise decision-making authority in PB. Again, the survey respondents' attitudes are strongly correlated with the percentage of resources that the government allows citizens to negotiate.

\section{Belo Horizonte}

PB was adopted in Belo Horizonte in 1993 by a PT Mayor. PB was used by the mayor to solidify support among his civil society base, to reach out to unorganized citizens, and to demonstrate that the government was participatory and democratic, which are traits shared in common with the policy entrepreneurs in Porto Alegre and Ipatinga. What differentiates Belo Horizonte is that the governing coalition, which included the Brazilian Socialist Party, sought to initiate a broader range of policy reforms. PB was one instrument among many utilized by the government to pursue its policy and political aims whereas PB was the principal policy, governing, and electoral strategy for the PT governments in Porto Alegre and Ipatinga. In Belo Horizonte, citizens were initially given the right to negotiate over a third of the new capital spending (1993/1994), but by 2003 this had decreased to just 17 percent of the new capital spending, which demonstrates that the government did not dedicate as many resources to PB as in the entrepreneurial cases and that their support also decreased over time (Wampler 2007a). Citizens involved in the process were evenly split regarding their ability to exercise authority in PB (47 percent responding that they always or almost always exercise 
authority). The government spent US \$125 million on PB projects between 1996 and 2003, which is a significant amount of money spent on projects selected by low-income individuals in Brazil, but it pales in comparison to the US \$400 million spent in Porto Alegre, which has a smaller population and a lower annual municipal budget (Wampler 2007a).

Belo Horizonte’s political leadership reformed PB at the fringes but did not directly overhaul the basic model it adopted from Porto Alegre’s PB. For example, they established "PB Housing” in 1996 to streamline the process through which individuals without decent housing used the PB process to secure new housing. In 2002, they revised PB again to provide additional rights and access to individuals living in particularly dire and vulnerable populations. The ongoing changes made suggest that the government leadership was trying to improve the program but the decrease in funding suggests that the government's priorities shifted away from PB. Therefore, the PB policy had positive impacts but its overall effect was smaller than in Porto Alegre because the Belo Horizonte PT government did not privilege the PB program as a top priority.

\section{Recife}

PB was initiated in Recife in 1994 by a charismatic mayor from a centrist, catchall party (PMDB). Members of the mayor's staff traveled to Porto Alegre to gather information about the process. ${ }^{8}$ Recife’s municipal government initiated participatory practices as early as 1982 (still under the military dictatorship) but government officials looked to the Porto Alegre experience due to its purported successes (Soares 1998). In Recife, citizens were initially given the right to negotiate just 10 percent of the new 
capital investments (1995/1996), a figure that was maintained during the 1997-2000 period but increased to roughly 50 percent of the new capital investments in the 20012004 period (Wampler 2007a). The shift in resources allocated to PB was primarily driven by the fact that three mayors from three different parties governed Recife using PB. The mayor who initiated PB was from the centrist PMD. He sought to build a base of support among his civil society base but it was not the primary mechanism utilized to reach out to constituents who were not involved in civil society organizations. The PMDB did not want to build its party brand around a policy program that was associated with their rival, the Workers' Party. The second mayor was from a conservative party, the PFL, and he had served as a governor appointed by the military authoritarian regime. This mayor maintained PB due to an electoral alliance with the PMDB but provided the most minimal level of resources and support to PB, which resulted in very limited implementation of public works selected by citizens through PB. His mayoral administration is best classified as being a pro forma adopter because the mayor maintained the formal structure of PB but did very little to make it a viable policymaking institution.

The election of a Worker’ Party mayor in 2000 marks a significant turning point. The new mayor sought to revitalize PB in order to build a base of support, to reach out to constituents who might potentially support the newly elected government, and to brand the local PT as being able to accomplish significant policy changes via participatory practices. João Costa, PB’s head administrator, argued that the majority of elected PB delegates were allied with PMDB Mayor Jarbas Vasconcelos when the PT took over in 2001. Costa stated, "When we were elected, we wanted to break the associative tradition 
that induced CSO leaders to be the political operatives of Jarbas [Vasconcelos]."9 The government therefore sought to create a rapid expansion of participation to create a new base of support. The rules and processes of PB were substantially modified, including the holding of nearly 500 meetings in 2003 as a means to reach out to any interested citizen or group. The mayoral administration initiated a "PB kids and adolescents” program that was designed to educate teenagers (future citizens and voters) about the importance of participatory processes that allow citizens to be directly involved in budgeting affairs. The shifts in mayoral attention vis-à-vis PB best explains why just under half of the survey respondents believe that they could exercise authority. It is important to emphasize that the Workers’ Party government increased funding for PB but the government did not risk their entire political future on a program that had been initially adopted in Recife by their political rivals— $50 \%$ of new capital spending was decided by citizens, which is significant but, again, falls short of the Porto Alegre and Ipatinga experiences. The political payoffs were lower for Recife's mayors than their counterparts in Porto Alegre and Ipatinga, which explains why Recife’s mayors dedicated lower levels of funding.

\section{São Paulo}

PB was re-initiated in São Paulo in 2001 by the PT, following an eight-year hiatus. In 2002, a small, leftist faction within the PT promoted PB, but the program did not have the firm support of the mayor (Wampler 2004). Members of this minority faction occupied the majority of the administrative posts within $\mathrm{PB}$ and sought to use $\mathrm{PB}$ as a means to reward their base and to reach out to interested constituents. The principal 
leadership of the party, however, did not seek to use PB as a mechanism to re-brand the party and they also did not envision PB as a means to reach out to sectors of society that did not support them at the ballot box (Wampler 2004). In São Paulo, citizens were able to negotiate roughly 25 to 35 percent of new capital spending between 2001 and 2004, which is a potentially robust level (Wampler 2007a). Yet, many of the projects were initiated by the government, which meant that PB participants were rubberstamping policies already decided by the government’s inner circle (Wampler 2004 and 2007a). It is important to keep in mind, however, that PB delegates did enjoy some authority to make decisions - authority that had never previously been granted to citizens in São Paulo.

We can also conceptualize the government as policy advocates because they, like the cases of Belo Horizonte and Recife, sought to modify the rules in order to improve the program as well as to demonstrate to national party leaders and international policymakers that they were innovative. The specific innovation in São Paulo was the development of an "affirmative action” program that gave individuals from historically underrepresented groups (GLBT, black, indigenous, disabled, etc) the right to be elected to PB with far fewer votes. The establishment of this policy enhancement confirms that PB administrators were advocates who were interested in improving the quality of their program. Yet, the PB personnel was hamstrung by government leadership that was not interested in making PB a central part of its policy making process. The government in São Paulo is best conceptualized as policy advocates because one faction within the government sought to make PB a vibrant policy arena, but they were constrained because they lacked the support of the government's top leadership. 


\section{Santo André}

PB was initiated in Santo André in 1990 during the first of Celso Daniel's (PT) three mayoral terms. During the first term (1989-1992), Daniel was a policy entrepreneur with regard to PB, as his administration sought to design innovative strategies to incorporate citizens into the policy-making process. The PT lost the 1992 mayoral election but Daniel was elected to his second mayoral term in 1996. During the 19972000 period, Daniel shifted from being a policy entrepreneur to a policy advocate within the realm of PB. Daniel continued to be a policy entrepreneur in other areas, but PB decreased in importance in his government. What explains the transition?

First, Daniel won the 1996 election with 62\% and 2000 elections with $70 \%$ of the vote, which meant that he didn't need to use PB to reach out to constituents who didn't vote for the PT. Second, Santo André is a decaying industrial city, which meant that Daniel sought to work with labor unions, corporations, and capitalists to quell the flight of manufacturing plants from Santo André. To this end, Daniel created a participatory "Future City" institution, which brought together unions, government officials, and corporate leader to debate and make decisions about how to revitalize Santo André. This participatory institution occupied the focus on Daniel's policy energy, thereby decreasing the available support that could be given to PB. Finally, Daniel was a close advisor to the PT's perpetual candidate for President, Lula da Silva, and sought to use his administration to re-brand the local PT in a manner that would demonstrate that the moderate, "socialism lite” faction within PT could work closely with industrialists to 
produce mutually agreeable policy outcomes. For these reasons, then, Daniel was no longer a policy entrepreneur with regard to PB but had become a policy advocate.

In Santo André, elected PB delegates’ control fluctuated between 20 and 50 percent of new capital spending between 1997 and 2003, but the institutional rules were written in such a way that the government had a veto over all policy choices (Wampler 2007a). Authority was only partially extended to citizens because Daniel was unwilling to risk his political future on PB. Survey respondents' responses reflect this ambiguity as just over 40 percent believe that that they always or almost always have the authority to make decisions in PB.

In the four municipalities led by policy advocates, there were moderate levels of mayoral support for the delegation of authority, and citizens felt that they were able to make some important policy decisions. The evidence presented suggests that the adoption of best practices may not produce the intended effects because the incentive and pay-offs for the adopting governments are substantially lower than the pay-offs for the entrepreneurial governments. Therefore, it is necessary for NGOs, political parties, and citizens to more carefully consider the type of governments that will be responsible for implementing the best practice policies. The early adopters in Porto Alegre and Ipatinga created successful policies due to the resources dedicated by government officials to support the creation of new policy-making processes. These findings suggest that institutions that advocate the adoption of best-practice policies must more carefully consider the policy and political environments when they promote the adoption of these policies. 


\section{Conclusion}

What happens to innovative programs as they are adopted by governments in new political and policy environments? Participatory budgeting (PB) spread from its beginnings in the southern Brazilian city of Porto Alegre to more than 250 municipalities across Brazil; it has now spread to hundreds and perhaps even thousands of subnational governments across the globe (Goldfrank 2007b). The spread of PB programs in Brazil was initially driven by the electoral success and the internal discipline of the Workers' Party (PT), which resulted in all PT-governed large municipalities adopting PB. A second wave of adoption (1997-2004) was led by non-PT municipal governments seeking to gain governing and elections benefits from their association with a program that is known for its emphasis on social justice, transparency, and direct participation.

This article addresses the range of outcomes produced by governments that adopt PB. Are the adopting cases cheap knock-offs? Or are they high-quality replicas? Providing theoretical and empirical answers to these questions are vital because the World Bank and UN Habitat are now advocating the adoption of PB and similar policy programs across the globe. Although this advocacy is certainly understandable, and even commendable, it may not be prudent. Based on preliminary data, the policy outcomes produced by adopting cases appear to be sufficiently weaker than the initial set of cases (See figure 2). This suggests that a one-size-fits-all approach to institutional reform may be counter-productive because of the centrality of mayors to the PB process. Two new categories, policy advocates and pro forma adopters, were developed here to complement the more well-known concept of policy entrepreneur. 
Policy entrepreneurs produced the most successful programs because these governments’ political futures were tightly associated with the success of this particular program. It is, of course, possible that the World Bank and United Nations Habitat will find entrepreneurial politicians who are willing to delegate sufficiently high levels of authority to citizens in other towns, cities, states and provinces. Among adopting cases, however, it is more likely that these cases will be the exceptions rather than the norm because few elected politicians are willing to turn their newly won authority over to citizens. It is more likely that the vast majority of new cases will be adopted by policy advocates and pro forma adopters because elected officials will not necessarily be willing to risk their political futures on the delegation of authority to citizens.

Policy advocates partially support some aspects of PB, but not to the same degree as the entrepreneurs because they are unwilling to base their political futures on this particular policy program. Policy advocates are often moderate reformers who are willing to experiment with new policy formats, which means that there may be some positive effects generated by their PB programs. International NGOs and funding agencies may want to seek out these types of governments as they hope to promote the use of best practice policies. In these cases, PB may generate some new forms of state-society relations, but we must also keep in mind that there may also be the reproduction of traditional forms of politics (such as clientelism or co-optation) that mark the politics of many developing world countries. These policies are implemented in manners that enable them to complement, rather than overhaul, existing state-society relations.

Pro forma adopters often establish PB programs that produce outcomes bearing little to no resemblance to the most successful cases. In these cases, the adoption of PB 
programs may cause disillusionment and cynicism among citizens and local policymakers who were "sold" on the benefits they would accrue if they adopted a best practice policy. The activists must then confront working in a new policy environment in which the outcomes are weak. Pro forma adopters may be induced by their political party, by their CSO allies, or by an international organization to adopt $\mathrm{PB}$, but if there is not a strong incentive for the government to delegate authority, it is more likely that cynicism, rather than empowerment, will be fostered. The presence of pro forma adopters should give considerable pause to national and international NGOs and funding agencies that promote the widespread adoption of best practices because their promotion of policies may not produce the intended effects.

This is not to argue that the promotion of best practices should not continue, but that we must greatly lower our expectations concerning the type of outcomes produced as well as reconsider where and when these programs should be adopted. It may be worthwhile for NGOs and international funding agencies to invest more time in identifying which governments are likely to be policy advocates versus those more likely to be pro forma adopters. It might be worthwhile for these organizations to reconceputalize the types of benefits that they provide to government officials as a means to induce them to support the innovative policies. Based on the evidence presented here, it may be advantageous to promote best practice policies among policy advocates governments but to discourage adoption among pro forma adopters. 


\section{Table 1}

Potential pay-offs for governments adopting innovative policies

\begin{tabular}{|l|c|c|c|}
\hline & Entrepreneur & Advocate & Pro forma adopters \\
\hline Reward Base & Strong & Strong & Limited \\
\hline $\begin{array}{l}\text { Reach out to new } \\
\text { constituents }\end{array}$ & Strong & Partial & Minimal \\
\hline $\begin{array}{l}\text { Re-brand party } \\
\text { image }\end{array}$ & Strong & Partial & Minimal \\
\hline $\begin{array}{l}\text { National policy } \\
\text { recognition }\end{array}$ & Strong & Partial & Minimal \\
\hline $\begin{array}{l}\text { National intra-party } \\
\text { recognition }\end{array}$ & Strong & Limited & Minimal \\
\hline
\end{tabular}

Figure 1

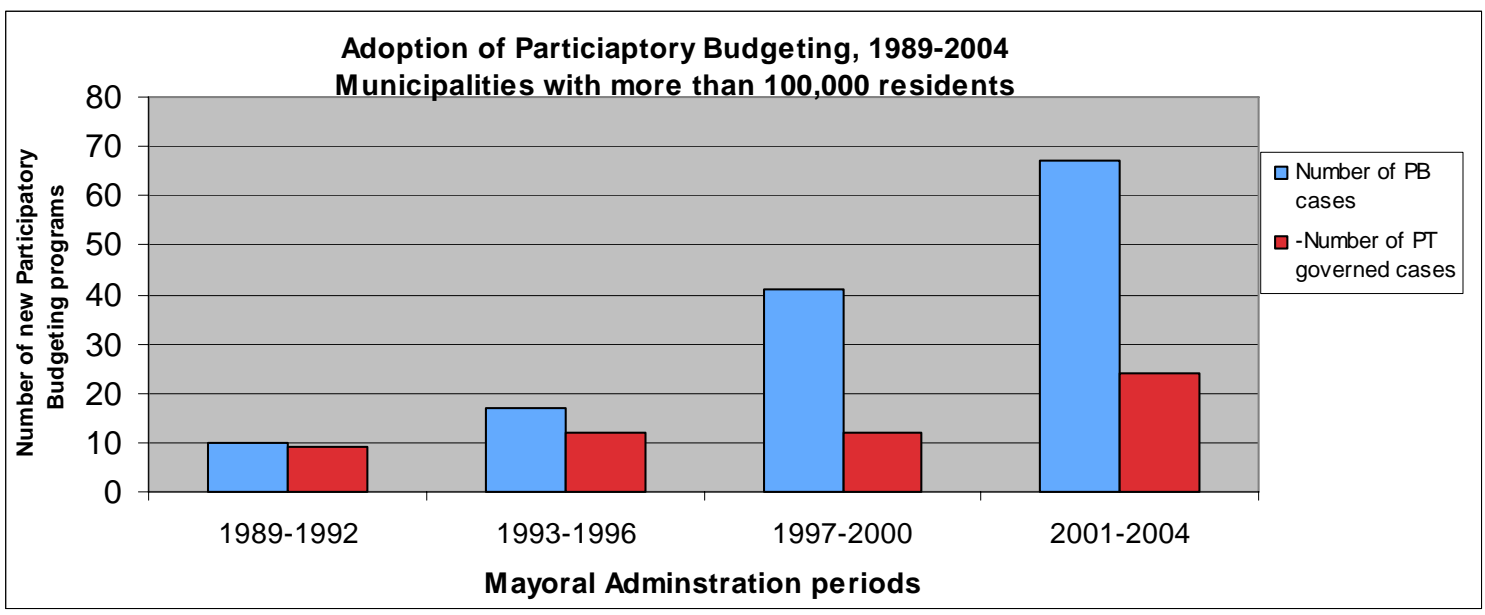


Figure 2

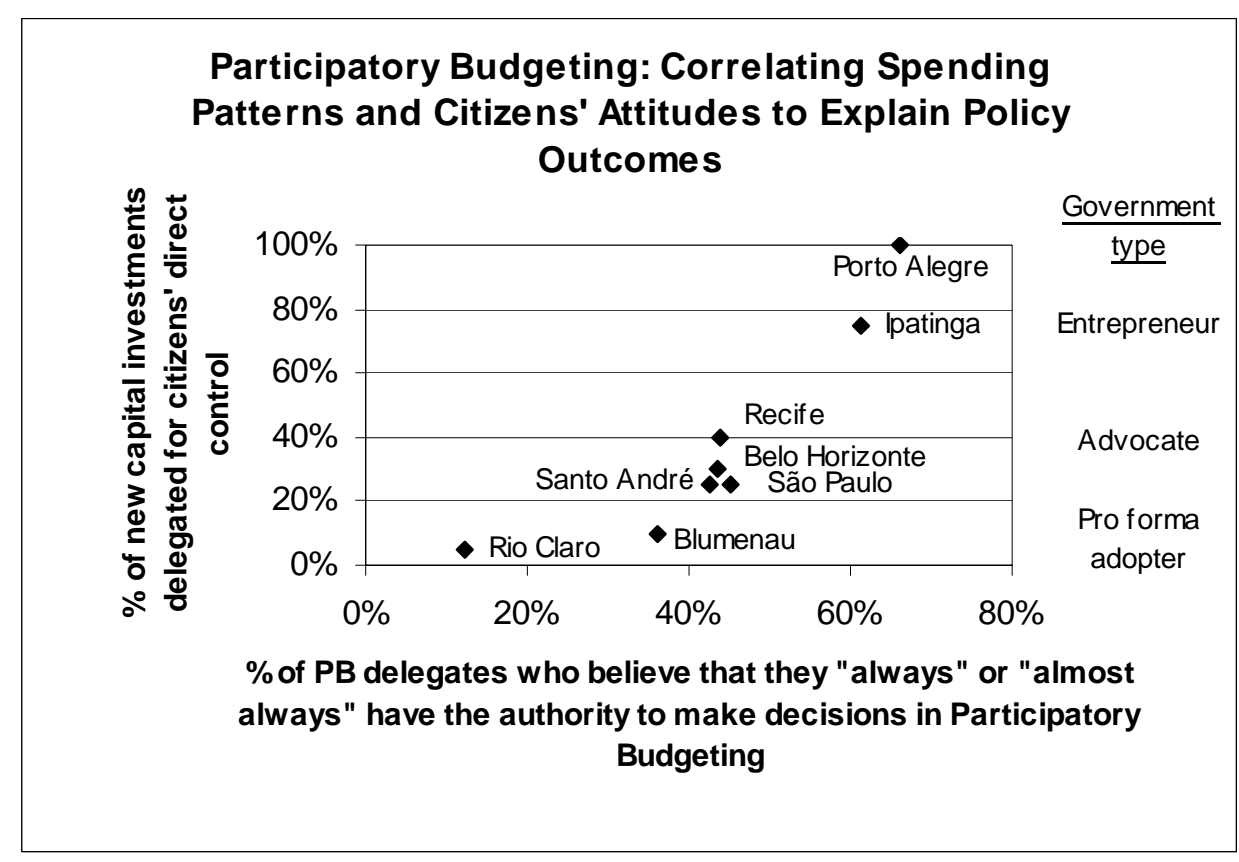




\section{Bibliography}

Abers, Rebecca. (2000). Inventing Local Democracy: Grassroots Politics in Brazil. Boulder: Westview.

Andrade, Edinara. 2001. "Desafios de democracia participative: O Orçamento Participativo de Blumenau e seu impacto sobre as associações de moradores.” Blumeanu: Regional University of Blumenau

Avritzer, Leonardo. (2002). Democracy and the public space in Latin America. Princeton: Princeton University Press.

Baiocchi, Gianpaolo. (2005). Militants and Citizens: The Politics of Participatory Democracy in Porto Alegre. Stanford: Stanford University Press.

Baumgartner, Frank and Bryan Jones. (1993). Agendas and Instability in American Politics. Chicago: University of Chicago Press.

Cabannes, Yves. 2004. "Participatory Budgeting: A significant contribution to participatory democracy.” Environment and Urbanization. 16 (1): 27-46.

Couto, Cláudio Gonçalves. (1995). O Desafio de ser Governo: O PT na Prefeitura de São Paulo (1988-1992). Rio de Janiero: Paz e Terra.

Fedozzi, Luciano. (1998). Orçamento participativo: Reflexões sobre a experiência de Porto. Porto Alegre: Tomo Editorial.

Genro, Tarso. (1995). Utopia Possível, $2^{\text {nd }}$ edition. Porto Alegre: Artes e Ofícios. Goldfrank, Benjamin. (2007a) "The Politics of Deepening Local Democracy: Decentralization, Party Institutionalization, and Participation," Comparative Politics, 39 (January), 147-168. . (2007b). "Lessons from Latin America’s Experience with Participatory Budgeting.” In Participatory Budgeting. Edited by Anwar Shah. Washington, D.C.: World Bank.

Grindle, Marilee. (2000). Audacious reforms: Institutional invention and democracy in Latin America. Balitmore, MD: Johns Hopkins University Press.

Heller, Patrick. 2000. "Degrees of Democracy: Some Comparative Lessons from India.” World Politics 52(4):484-519.

Hunter, Wendy (2004). From opposition movement to government party: Growth and expansion of the Workers' Party in Brazil. Paper presented at the $100^{\text {th }}$ annual meeting of the American Political Science Association meeting, Chicago, Illinois. September 4-6, 2004.

Keck, Margaret E. 1992. The Workers' Party and Democratization in Brazil. New Haven: Yale University Press.

Kingdon, John W. (1995). Agendas, Alternatives, and Public Policies. New York: Longman. $2^{\text {nd }}$ edition.

Marquetti, Adelmir. 2003. "Democracia, Equidade e Effciencia, o Caso do Orçamento Participativo em Porto Alegre.” In Leonardo Avritzer and Zander Navarro, eds., A Inovação Democrática no Brasil: O Orçamento Participativo. São Paulo: Cortez Editores.

Martinez, Fernanda. 2003. “A Democracia Digital.” Programa Gestão Público e Cidadania and Getulio Vargas Foundation. Pp. 75-78.

Martinez, Fernanda, Jose Carlos Vaz, and Winthrop Carty. 2004. "Internet use and Citizen Participation in Local Government: Ipatinga’s Interactive Participatory Budgeting.” Boston: Ash Institute, Harvard University. 
Mintrom, Michael. (1997). Policy entrepreneurs and the diffusion of innovation. American Journal of Political Science, 41(3), 738-770.

Montero, Alfred P. (2000). "Devolving Democracy? Political Decentralization and the New Brazilian Federalism.” In Peter R. Kingstone and Timothy J. Power, eds., Democratic Brazil: Actors, Institutions, and Processes. Pittsburgh: University of Pittsburgh Press.

Montero, Alfred, and Samuels, David. (2004). Decentralization and democracy in Latin America. Notre Dame, Ind.: University of Notre Dame Press.

Navarro, Zander. 2003. “O ‘Orçamento Participativo’ de Porto Alegre (1989-2002): Um conciso comentário crítico.” In Leonardo Avritzer and Zander Navarro, eds., A Inovação Democratica no Brasil. São Paulo: Cortez

Nylen, William R. (2003). Participatory Democracy versus Elitist Democracy: Lessons from Brazil. New York: Palgrave Macmillan.

Samuels, David. (2004). "From Socialism to Social Democracy: Party Organization and the Transformation of the Workers’ Party in Brazil.” Comparative Political Studies, 37(9): 999-1024.

Shah, Anwar. 2007. Participatory Budgeting. Washington, D.C.: World Bank.

Soares, José Arlindo. 1998. Os Desafios de Gestão Municipal Democrática: Recife. Recife: Cenro Josué de Castro.

Torres, Clara, Ana, and Grazia, Grazia de (2003). Experiências de Orçamento Participativo no Brasil: Periodo de 1997 a 2000. São Paulo: Editora Bozes.

Tendler, Judith. (1997). Good Government in the Tropics, Baltimore, MD: Johns Hopkins University Press

Teixeira, Ana Cláudia Chaves, and Maria do Carmo Albuquerque. (2005). Orçamentos Participativos: rojetos politicos, partilha de poder e alcance democrático. Instituto Pólis.

Wampler, Brian, and Avritzer, Leonardo. (2005). “The spread of Participatory Democracy in Brazil: From Radical Democracy to Participatory Good Government. Journal of Latin American Urban Studies. 7: 37-52.

(2004). Participatory publics: Civil society and new institutions in democratic Brazil. Comparative Politics, 36(3): 297-312.

Wampler, Brian. (2007a). Participatory Budgeting in Brazil: Contestation, Cooperation, and Accountability. University Park: Pennsylvania State Press.

(2007b). "Can Participatory Institutions Promote Pluralism? Mobilizing LowIncome Citizens in Brazil.” Studies in Comparative International Development. 41(4): 57-79.

.2004. "Instituições, Associações e Interesses no Orçamento Participativo do São Paulo.” In Associativismo em São Paulo. Edited by Leonardo Avritzer. (São Paulo: Edusp).

\section{Interviews}

Assis, Franciso; Secretary of Social Policy, Recife (1997-1999); September 8, 1998, Recife. Costa, João. Head PB Administrator (2001-2007); December 9, 2003

Fedozzi, Luciano; Professor, Former Administrator; May 25, 1999, Porto Alegre.

Grazia, Grazia de; FASE NGO; October 24, 2003, Brasilia.

Soler, Salvador; Secretary of Social Policy, Recife (1993-1996); October 6, 1998, Recife.

Villas Boas, Renata; Former POLIS employee; May 6, 2004, São Paulo. 


\section{Endnotes}

${ }^{1}$ www.bestpractices.org
2 For a more extensive description of the rules, please see
http://www.internationalbudget.org/resources/library/GPB.pdf. Accessed on October 25, 2006.

${ }^{3} \mathrm{~PB}$ programs have been implemented in Brazilian cities with populations ranging from 4,000 to 10 million residents. Comparing PB within the universe of all of Brazil's 5,500 municipalities would not only be a quixotic data collection enterprise but would not likely provide the basis for any meaningful explanation because of the vast regional, economic, political, and social differences among these municipalities. To establish a solid methodological grounding for this study and to create the opportunity for gaining some theoretical insights, only municipalities with more than 100,000 residents (2000 Brazilian Census) are included in the data collection.

${ }^{4}$ The criteria for selection were based on several criteria: Municipalities had to have had a functioning PB for at least 7 years between 2003 and 1989. Municipalities had to have a population of at least 100,000 residents. 31 municipalities met this criteria. I selected the eight based on regional diversity, political party that originated $\mathrm{PB}$, and population. ${ }^{5}$ The survey was field-tested and designed with the help of Gustavo Venturi. The survey was conducted by the Instituto Ethos between November 25 and December 10, 2003. Survey methodology: This survey is a representative sample of PB delegates rather than a random survey of PB delegates. There were 695 total surveys completed out of 6500 possible participants. The distribution among the different municipalities was: Porto Alegre (60), Ipatinga (60), Belo Horizonte (60), Santo Andre (60), São Paulo (300), Recife (60), Blumenau (60), and Rio Claro (30). In all cities, with the exception of Santo Andre, the surveys were conducted via telephone. To generate an appropriate phone list of current delegates, the author contacted each municipal government to obtain the names and phone numbers of individuals who were serving as PB delegates in 2003. In the municipalities of São Paulo, Ipatinga, Blumenau, Rio Claro, and Recife, complete lists of all delegates were obtained. Individuals were then randomly selected. In Porto Alegre and Belo Horizonte, municipality management of names and phone numbers was

decentralized at a submunicipal level. In Porto Alegre, we were able to obtain $50 \%$ of the appropriate numbers, from which we generated a random selection. In Belo Horizonte, we obtained less than $30 \%$ of potential names and phone numbers, from which we generated a random selection. In Santo Andre, surveys were conducted inperson at PB neighborhood meetings.

${ }^{6}$ For a more extended analysis of all eight cases, see Wampler 2007.

${ }^{7}$ Interview with former PB delegate and current PB administrator Sadi. January 10, 2004. She was a former community leader hired by the government on a part-time basis to help run PB.

${ }^{8}$ Soler interview.

${ }^{9}$ Interview with João Costa, December 9, 2003. 